\title{
Geochemical evidence for melting of carbonated peridotite on Santa Maria Island, Azores
}

\author{
Christoph Beier · João Mata · Ferdinand Stöckhert • Nadine Mattielli • \\ Philipp A. Brandl - Pedro Madureira • Felix S. Genske - Sofia Martins • \\ José Madeira $\cdot$ Karsten M. Haase
}

Received: 16 July 2012/ Accepted: 15 November 2012

(C) Springer-Verlag Berlin Heidelberg 2012

\begin{abstract}
The islands of the Azores archipelago emerge from an oceanic plateau built on lithosphere increasing in age with distance from the Mid-Atlantic Ridge from 10 to $45 \mathrm{Ma}$. Here, we present the first comprehensive major and trace element and $\mathrm{Sr}-\mathrm{Nd}-\mathrm{Pb}$ isotope data from Santa Maria, the easternmost island of the archipelago, along with published data from the other Azores islands situated
\end{abstract}

Communicated by J. Hoefs.

Electronic supplementary material The online version of this article (doi:10.1007/s00410-012-0837-2) contains supplementary material, which is available to authorized users.

C. Beier $(\bowtie) \cdot$ F. Stöckhert · P. A. Brandl •

F. S. Genske - K. M. Haase

GeoZentrum Nordbayern, Universität Erlangen-Nürnberg,

Schloßgarten 5, 91054 Erlangen, Germany

e-mail: Christoph.Beier@fau.de

J. Mata · S. Martins

Centro de Geologia, Departamento de Geologia,

Faculdade de Ciências, Universidade de Lisboa,

FCUL, Campo Grande C6, 1749-016 Lisbon, Portugal

N. Mattielli

Laboratoire G-Time CP160/02, Université Libre de Bruxelles, Avenue F.D. Roosevelt 50, 1050 Brussels, Belgium

\section{P. Madureira}

Estrutura de Missão para a Extensão da Plataforma Continental, R. Costa Pinto, 165, 2770-047 Paço de Arcos, Portugal

P. Madureira

Centro de Geofísica de Évora, Dep. Geociências, Universidade de Évora, R. Romão Ramalho, 59, 7000 Évora, Portugal

\section{J. Madeira}

Instituto D. Luiz, Departamento de Geologia,

Faculdade de Ciências, Universidade de Lisboa,

FCUL, Campo Grande C6, 1749-016 Lisbon, Portugal much closer to the Mid-Atlantic Ridge axis. We can show that the distinctively more variable and more enriched trace element ratios at Santa Maria combined with a relatively small range in $\mathrm{Sr}-\mathrm{Nd}-\mathrm{Pb}$ isotope ratios are the result of low degrees of partial melting of a common Azores mantle plume source underneath thicker lithosphere. This implies that melt extraction processes and melting dynamics may be able to better preserve the trace element mantle source variability underneath thicker lithosphere. These conclusions may apply widely for oceanic melts erupted on relatively thick lithosphere. In addition, lower Ti/Sm and $\mathrm{K} / \mathrm{La}$ ratios and $\mathrm{SiO}_{2}$ contents of Santa Maria lavas imply melting of a carbonated peridotite source. Mixing of variable portions of deep small-degree carbonated peridotite melts and shallow volatile-free garnet peridotite could explain the geochemical variability underneath Santa Maria in agreement with the volatile-rich nature of the Azores mantle source. However, Santa Maria is the Azores island where the $\mathrm{CO}_{2}$-rich nature of the mantle source is more evident, reflecting a combination of a smaller extent of partial melting and the positioning at the edge of the tilted Azores mantle plume.

Keywords Ocean Island Basalts · Azores · Lithosphere thickness · Melting dynamics - Carbonated peridotite

\section{Introduction}

Basalts erupted at Ocean Islands (OIB) display a larger trace element and isotopic variability compared to those erupted along mid-ocean ridges (MOR) (e.g., Dupré and Allègre 1983; Hofmann 1997; Hofmann 2003; McKenzie and O'Nions 1995; Salters and White 1998; Stracke et al. 2003). In addition to shallow-level processes such as 